International Journal of Advanced Academic Research (Sciences, Technology and Engineering) | ISSN: 2488-9849

Journal DOI: 10.46654/ij.24889849

Vol. 6, Issue 12 (December, 2020) | www.ijaar.org

Article DOI: 10.46654/ij.24889849.e61218

\title{
PHYSIOCHEMICAL ANALYSIS OF DESERT DATE (BALANITE AEGYPTIACA) SEED OIL FOR INDUSTRIAL AND DOMESTIC PURPOSES
}

\author{
M.M Kibiya and Ishaq Bala Adam \\ Department of Mechanical Engineering, Kano State Polytechnic, Nigeria.
}

Corresponding author:ishaqbala2008@gmail.com, +2348034532523

\begin{abstract}
The desert date seeds were collected from Gomo, washed, decocted, dried, and pulverized. The seed oil was extracted using soxhlet apparatus with $n$ - hexane as solvent. The percentage yield of the extracted oil was found to be 40.5\%. While the physicochemical analysis of the seed oil was conducted using standard procedures with the following results; specific density $0.98 \mathrm{~g} / \mathrm{cm}^{3}$, saponification value $134 \mathrm{mgKOH} / \mathrm{g}$, peroxide value $38 \mathrm{meq} / \mathrm{kg}$, acid value $12.6 \mathrm{mgKOH} / \mathrm{g}$, free fatty acid value $12.7 \mathrm{mgKOH} / \mathrm{g}$. These results indicate that Desert date seed oil could be a rich source of oil for industrial and domestic purposes if exploited richly.
\end{abstract}

Key words: Balanites Aegyptiaca, soxhlet apparatus, n- hexane, biomass, edible. 


\subsection{Introduction}

Plant oils represent one of the key materials that can be obtained cheaply from biomass and processed readily to supply the appropriate raw material for chemical industries(Ogala, Elinge, Wawata, Adegoke, Muhammad, \& Ige, April, 2018). Plant oils have both edible and non edible applications e.g lubricants, cosmetics, soap production, biodiesel and insulating materials(Ogala, Elinge, Wawata, Adegoke, Muhammad, \& Ige, April, 2018). But in our country Nigeria, oils are produced from groundnut, coconut, moringa, jatropha, castor etc. while there are other potential sources of oil in which the country still is not utilizing. Balanites Aegyptiaca plants fruit is one of the sources of oil rich fruit product that must be used in order to increase the oil yield to fulfil the demand of the people and to upgrade the oil quality in order to protect people from health risk.

Balanites Aegyptiacais a species of tree, deep rooted ever green or semi deciduous tree up to $12 \mathrm{~m}$ high. Classified either as a member of the zygophyllaceae or Balanitaceae. It is multi branched and the flowers are small. The plant grows in tropical and desert areas. It can be found in many kinds of habitats, tolerating a wide variety of soil types from sand to heavy clay and climatic moisture (Ogala, Elinge, Wawata, Adegoke, Muhammad, \& Ige, 2018). Balanites Aegyptiaca is perennial plant used in food preparations, especially in Africa and developing countries. It has multiplicity of uses and almost every part of the plant is useful including, leaves thorns, back of root and fruit. The fruit is used to treat liver disease.

It is very tolerant to drought and thrives with an annual rainfall of $200 \mathrm{~mm}$ or less where there is an additional water supply e.g. banks of Nile in Sudan. It spreads from the margin of the desert to the woody Savannahs with up to $900 \mathrm{~mm}$ of annual rainfall. It prefers deep sandy loam soils and uninterrupted access to water such as valley floors, riverbanks or the foot of rocky slopes. It can run wild in abundant environments and become a weed. Balanites Aegyptiaca seed kernel is considered as an extremely useful edible product. The Balanites Aegyptiaca seed oil has been used in many countries as ingredient and substituent to groundnut oil in the preparation of local food (Ogala, Elinge, Wawata, Adegoke, Muhammad, \& Ige, 2018).

\subsection{Material and Method}

\subsection{Sample collection and treatment}

The desert date fruits were obtained from Gomo in Sumaila Local Government of Kano State. After collection they were sundried and their shells cracked using metal hammer to obtain their seeds. The dried seeds were crushed into cake using motor and pestle in order to weaken the cell walls to release fat for extraction. 
Journal DOI: 10.46654/ij.24889849

Vol. 6, Issue 12 (December, 2020) | www.ijaar.org

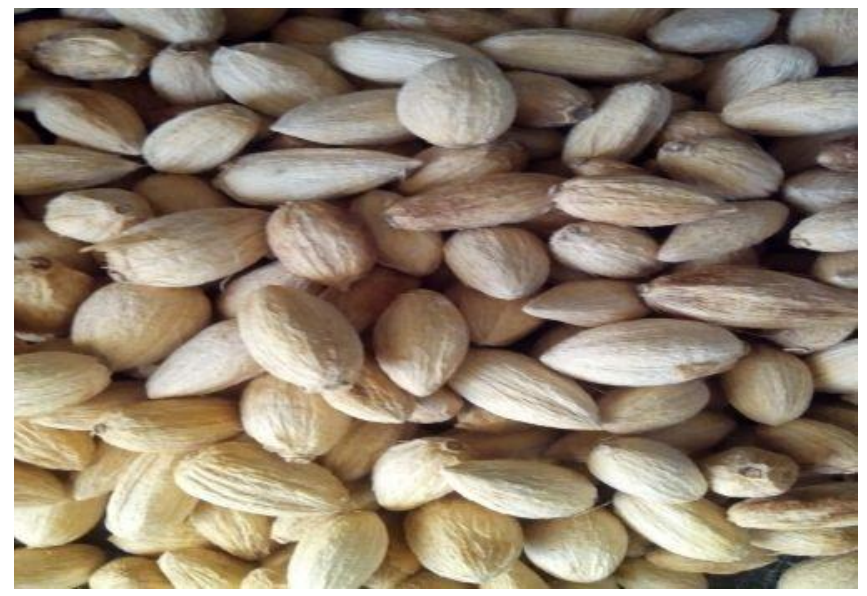

\subsection{Extraction of Desert date seed oil}

About 200ml n- hexane was measured and then poured into a round bottom flask. A sample weighing $100 \mathrm{~g}$ was placed in the thimble and then inserted in the centre of the extractor. The solvent was heated to $70^{\circ} \mathrm{C}$ and when the solvent boiled, the vapour rose through the vertical tube into the condenser at the top. The liquid condensate dripped into the filter paper thimble in the centre which contained the solid sample to be extracted. The extract seeped through the pores of the thimble and filled the siphon tube then flowed back down into the round bottom flask. This was allowed to continue for about 5hours so as to maximize the oil yield (Ogala, Elinge, Wawata, Adegoke, Muhammad, \& Ige, April, 2018). 


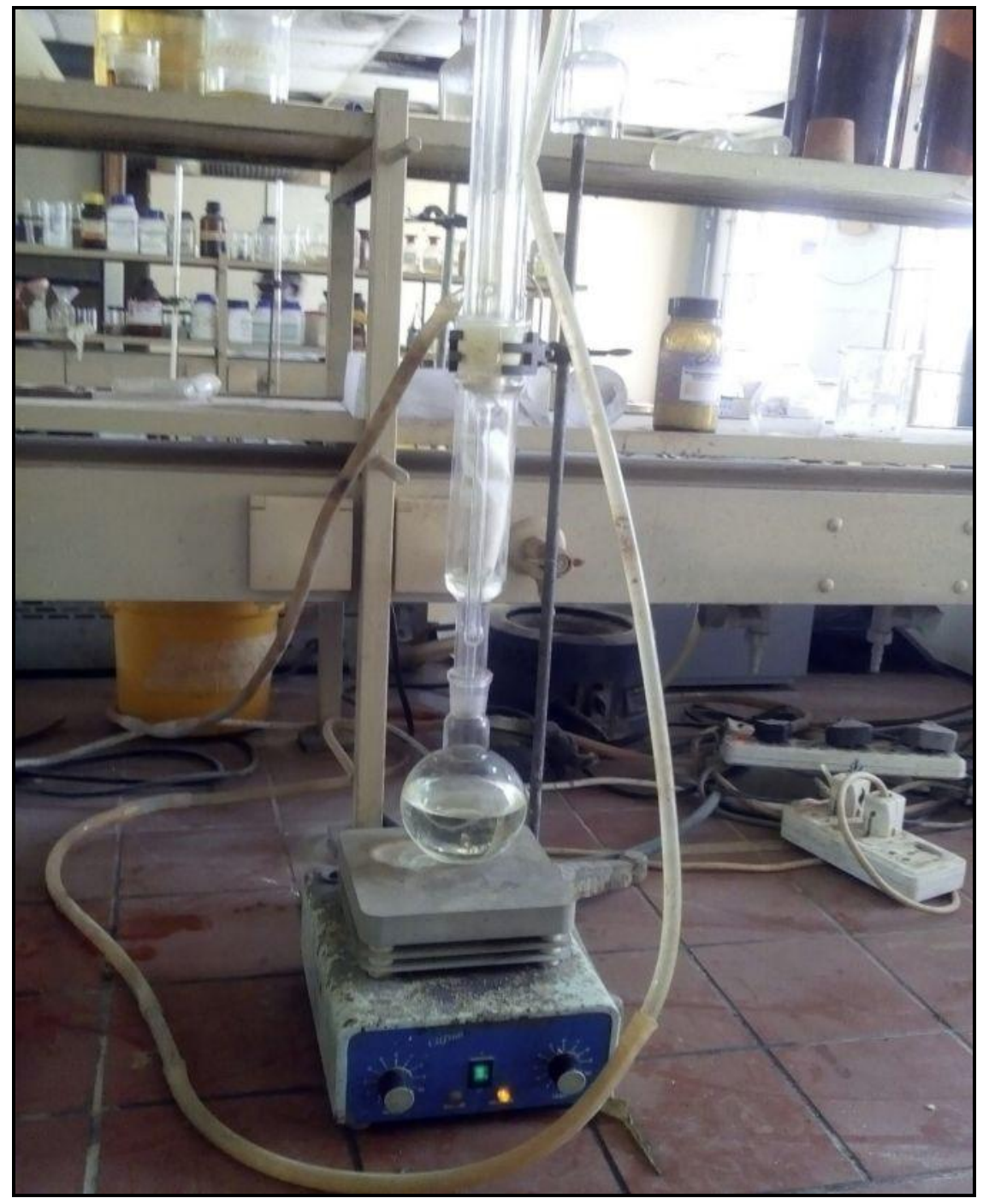

\subsection{Determination of Physical Parameters}

\subsubsection{Colour}

The colour of the extracted seed oil was observed visually.

\subsubsection{Determination of Moisture Content of the Seeds}

$30 \mathrm{~g}$ of the clean sample was weighed and then dried in the oven at $80^{\circ} \mathrm{C}$ for hours and the weight was recorded after every 2 hour. The same procedure was repeated until a constant weight was obtained. The sample was then removed from the oven and placed in the desiccator for 
30minutes to cool then removed and reweighed. The $\%$ moisture content in the seeds was calculated using equation (1).

$$
\% \text { Moisture }=\left(W_{1}-W_{2} / W_{1}\right) \times 100 \ldots \ldots \ldots \ldots \ldots . \ldots 1
$$

Where $\mathrm{W}_{1}=$ Weight of the sample before drying and $\mathrm{W}_{2}=$ Weight of thesample after drying.

\subsubsection{Determination of Percentage Yield}

The percentage yield can be obtain using the relation of the below equation as reported by (Ogala, Elinge, Wawata, Adegoke, Muhammad, \& Ige, April, 2018). The oil obtained from the extraction was transferred into a measuring cylinder which was placed over a water bath for 30 minutes at $70^{\circ} \mathrm{C}$ so as to ensure complete evaporation of the solvent and then the volume of the oil was recorded using equation (2).

$$
\% \text { Yield }=\left(W_{1} / W_{2}\right) \times 100 \ldots \ldots \ldots \ldots \ldots \ldots . . .2
$$

Where $\mathrm{W}_{1}=$ Weight of oil extracted and $\mathrm{W}_{2}=$ Weight of sample used

\subsubsection{Refractive index}

The refractive index was determined using the Abbe's refractometer. It measures the index of refraction by measuring the critical angle of total refraction. In this case, a few drops of the sample were transferred into the glass slide of the refractometer. Water at $30^{\circ} \mathrm{C}$ was circulated round the glass slide to keep its temperature uniform. Through the eyepiece of the refractometer, the dark portion viewed was adjusted to be in line with the intersection of the cross. The pointer on the scale pointed the refractive index at no parallaxerror.

\subsubsection{Determination of Specific Density}

Density is the ratio of mass to volume and depends on the fatty acid composition and minor components as well as on the temperature (Ogala, Elinge, Wawata, Adegoke, Muhammad, \& Ige, April, 2018). If an oil has low density, it indicates that it contain low molecular weight fatty acids and it will have high saponification value which means it can be used for soap production (Afolabi, 2008).

About $25 \mathrm{ml}$ of the oil was measured in a pre- weighed measuring cylinder. The weight of the cylinder and the oil was taken; the weight of the oil was obtained by subtracting the weight of the cylinder from the weight of the oil and the cylinder. The specific density of the oil is obtained using equation (3) (John, 2008).

$$
\mathrm{S} . \mathrm{D}=\frac{W_{1}-W_{2}}{V_{0}} \ldots \ldots \ldots \ldots \ldots \ldots \ldots \ldots \ldots \ldots \ldots \ldots
$$

Where $\mathrm{W}_{1}=$ Weight of empty measuring cylinder + oil; $\mathrm{W}_{2}=$ Weight of measuring cylinder and $\mathrm{V}_{\mathrm{O}}=$ Volume of oil. 


\subsection{Determination of Chemical Parameters}

\subsubsection{Acid Value}

A $2.0 \mathrm{~g}$ of the oil sample was placed in $250 \mathrm{ml}$ conical flask followed by $25 \mathrm{ml}$ of the absolute ethanol and three drops of phenolphthalein indicator. The mixture was then heated in a shaking water bath for 5minutes. While hot, titrated against $0.1 \mathrm{M} \mathrm{KOH}$ until pink colour appeared. Vigorous shaking was done when approaching the end point to ensure thorough mixing. The volume of $0.1 \mathrm{M} \mathrm{KOH}$ consumed by an acid was recorded. The acid value was calculated as reported using equation (4) (Kyari, 2008).

$$
\mathrm{A} . \mathrm{V}=56.1 \times V \times M / m \ldots \ldots \ldots \ldots \ldots \ldots . . .4
$$

Where $\mathrm{V}=$ Volume of $\mathrm{KOH}$ used; $\mathrm{M}=$ Molarity of $\mathrm{KOH}$ and $\mathrm{m}=$ Mass of the sample.

\subsubsection{Iodine Value}

About $0.25 \mathrm{~g}$ of the oil sample in $250 \mathrm{ml}$ conical flask was added to $10 \mathrm{ml}$ of chloroform followed by $30 \mathrm{ml}$ of Hanus iodine solution. The flask was securely closed and the solution was left shaken for 30 minutes in the dark. This was followed by adding $10 \mathrm{ml}$ of $15 \%$ potassium iodine solution and then shaken after which $100 \mathrm{ml}$ of distilled water was added. The mixture was then titrated with the iodine solution against $0.1 \mathrm{M}$ Sodium thiosulphate solution till a yellow colour is formed. This was followed by addition of 2-3 drops of starch solution after which a blue solution is formed. The titration continued until the blue colour disappeared while the volume of $\mathrm{Na}_{2} \mathrm{~S}_{2} \mathrm{O}_{3}$ at end point was recorded. The iodine value I.V was calculated using equation (5) (AL-Hamdany \& Jihad, 2006).

$\mathrm{I} . \mathrm{V}=12.69 \times C\left(V_{1}-V_{2}\right) / m \ldots \ldots \ldots \ldots \ldots . . .5$

Where $\mathrm{C}=$ concentration of $\mathrm{Na}_{2} \mathrm{~S}_{2} \mathrm{O}_{3}$ used; $\mathrm{V}_{1}=$ volume of $\mathrm{Na}_{2} \mathrm{~S}_{2} \mathrm{O}_{3}$ used for the blank; $\mathrm{V}_{2}=$ volume of $\mathrm{Na}_{2} \mathrm{~S}_{2} \mathrm{O}_{3}$ used for the sample and $\mathrm{m}=$ mass of the sample.

\subsubsection{Saponification Value}

About $2 \mathrm{~g}$ sample of the oil was weighed into a $250 \mathrm{ml}$ glass conical flask, and then $10 \mathrm{ml}$ of ehanol ether mixture (2:1) was added to the same flask followed by $25 \mathrm{ml}$ of $0.5 \mathrm{~N}$ ethanolic potassium hydroxide. The flask was then fitted to a reflux condenser and refluxed using a boiling water bath for 30 minutes with occasional shaking. To the warm solution were added 3- 4 drops of phenolphthalein indicator and the warm solution was titrated against $0.5 \mathrm{M} \mathrm{HCl}$ to the end point. The same procedure was used for other samples and blank. The expression for saponification value (S.V) is calculated using equation (6) (Kyari, 2008). 
$\mathrm{S} . \mathrm{V}=56.1 \times M \times(B-R) / m \ldots \ldots \ldots \ldots \ldots \ldots \ldots$

Where $\mathrm{B}=$ volume of the solution used for blank test; $\mathrm{R}=$ volume of the solution used for determination; $\mathrm{M}=$ molarity of $\mathrm{HCl}$ used and $\mathrm{m}=$ mass of the sample.

\subsubsection{Peroxide Value}

Into a $250 \mathrm{ml}$ Erlenmeyer flask, $2 \mathrm{~g}$ of the oil sample, $1 \mathrm{ml}$ of potassium iodine and $20 \mathrm{ml}$ of solvent mixture (glacial acetic acid/ chloroform, $3 / 2$ by volume) were added and the mixture was boiled for one minute. The hot solution was poured into a flask containing $20 \mathrm{ml}$ of $5 \%$ potassium iodine. Thereafter 3 drops of starch solution were added to the mixture and the latter was titrated with $0.1 \mathrm{M}$ standardized sodium thiosulphate and the peroxide value was determined following the method reported by(Akpan, Jimoh, \& Mohammed, Extraction, Characterization and Modification of Castor Seed Oil, 2006) using equation (7).

$\mathrm{P} . \mathrm{V}=V \times M \times 100 /{ }^{\prime} \ldots \ldots \ldots \ldots \ldots . \ldots 7$

Where $\mathrm{V}=$ volume of $\mathrm{Na}_{2} \mathrm{~S}_{2} \mathrm{O}_{3} ; \mathrm{M}=$ molarity of $\mathrm{Na}_{2} \mathrm{~S}_{2} \mathrm{O}_{3}$ and $\mathrm{W}=$ weight of oil sample $(\mathrm{g})$

\subsubsection{Free fatty acid (FFA)}

About $2 \mathrm{~g}$ of the oil sample was placed in a $250 \mathrm{ml}$ conical flask and warmed while $2.5 \mathrm{ml}$ of methanol was added with thorough stirring, followed by 2 drops of phenolphthalein indicator and a drop of $0.14 \mathrm{M}$ potassium hydroxide solution. The content was then titrated against $0.14 \mathrm{M}$ potassium hydroxide solution while shaking vigorously until a permanent light pink colour which persisted for 1 minute was observed. The end point was recorded (Afolabi, 2008). The FFA value was calculated using equation (8).

$\% \mathrm{FFA}=V \times M \times 28.2 / W \ldots \ldots \ldots \ldots \ldots \ldots . . .8$

Where $\mathrm{V}=$ volume of $\mathrm{KOH}$ used; $\mathrm{M}=$ molarity of $\mathrm{KOH}$ and $\mathrm{W}=$ weight of the sample. 
Journal DOI: 10.46654/ij.24889849

Vol. 6, Issue 12 (December, 2020) | www.ijaar.org

Article DOI: 10.46654/ij.24889849.e61218

\subsection{Results and Discussion}

Table 1. Physical Properties of Desert date seed oil

\begin{tabular}{|l|l|l|}
\hline $\mathrm{S} / \mathrm{N}$ & Analysis & Result \\
\hline 1. & Colour & Pale yellow \\
\hline 2. & Odour & Mild \\
\hline 3. & State at room temperature & Liquid \\
\hline 4. & \% Yield & 40.5 \\
\hline 5. & Moisture content $(\%)$ & 8.2 \\
\hline 6. & Specific density $\left(\mathrm{g} / \mathrm{cm}^{3}\right)$ & 0.98 \\
\hline 7. & Refractive index & 1.33 \\
\hline
\end{tabular}

Table 2. Chemical properties of Desert date seed oil

\begin{tabular}{|l|l|l|}
\hline 2 & Analysis & Result \\
\hline 1. & Saponification value & 134 \\
\hline 2. & Iodine value & 42.6 \\
\hline 3. & Peroxide value & 38 \\
\hline 4. & Acid value & 12.6 \\
\hline 5. & Free fatty acid value & 12.7 \\
\hline
\end{tabular}

\section{Percentage yield}

The $\%$ Yield of the seed was found to be $40.5 \%$. This is found to be comparable to other various seed oil (Ogala, Elinge, Wawata, Adegoke, Muhammad, \& Ige, April, 2018).

The result of the refractive index 1.33 iswithin that obtained by (Ogala, Elinge, Wawata, Adegoke, Muhammad, \& Ige, April, 2018). This indicate that the oil is not as thick as most drying oils whose refractive index is within 1.48 - 1.49(Ogala, Elinge, Wawata, Adegoke, Muhammad, \& Ige, April, 2018). 
Journal DOI: 10.46654/ij.24889849

Vol. 6, Issue 12 (December, 2020) | www.ijaar.org

\section{Saponification value}

High saponification values indicate high proportion of lower fatty acid. The value of the saponification of the desert date seed oil was $134 \mathrm{mg} \mathrm{KOH} / \mathrm{g}$. This indicates that the oil could be used in the manufacture of soap (Kirschenbauer, 1995) which is comparable to $136 \mathrm{mg} \mathrm{KOH} / \mathrm{g}$ as presented by (Ogala, Elinge, Wawata, Adegoke, Muhammad, \& Ige, April, 2018).

\section{Iodine value}

Desert date seed oil can be classified as a non - drying oil as a resultits iodine value of $42.6 \mathrm{~g} / 100 \mathrm{~g}$ indicates that the oil contains high level of unsaturated fatty acid and is responsible for the liquid state of the oil at room temperature. The iodine value obtained agrees with $43.1 \mathrm{~g} /$ $100 \mathrm{~g}$ reported by (Ogala, Elinge, Wawata, Adegoke, Muhammad, \& Ige, April, 2018).

\section{Acid value and free fatty acid value}

The acid and the free fatty acid values obtained from the desert date seed oil were $12.6 \mathrm{mg}$ $\mathrm{KOH} / \mathrm{g}$ and $12.7 \mathrm{mg} \mathrm{KOH} / \mathrm{g}$ respectively which relatively agrees with that obtained by (Ogala, Elinge, Wawata, Adegoke, Muhammad, \& Ige, April, 2018).

\section{Peroxide value}

Peroxide value depends on the number of factors such as state of oxidation that is quantity of oxygen consumed, method of extraction and type fatty acid present in the oil. The seed oil has a peroxide value of $38 \mathrm{meq} / \mathrm{kg}$.

\subsection{Conclusion}

The preliminary investigation on the extraction and chemical analysis of the Desert date seed oil revealed that the oil is economically viable oil source due to its oil content was found to be high, the parameters showed it composed of moderately long chain fatty acids with a degree of unsaturation. This makes it a good feedstock for domestic and industrial purposes. 


\section{References}

Afolabi, S. (2008). Chemical qualities of oils from fresh and market vegetable crop within Kwara State, Nigeria. Niger Soc. Experim. Biol , 71-75.

Akpan, U., Jimoh, A., \& Mohammed, A. (2006). Extraction, Characterization and Modification of Castor Seed Oil. Leonardor Journal of Sciences , 43-52.

AL-Hamdany, A., \& Jihad, T. (2006). Oxidation of Some Primary and Secondary Alcohols Using Pyridinium Chlorochromate. Tikrit Journal of Pure Science, 17, 72-76.

John, K. (2008). Analytical Chemistry for Technicians. New Delhi, India: Lewis publishers, Kalyan publishers.

Kirschenbauer, H. (1995). Fats and Oils: An outline of their Chemistry and Technology. New York: Reinhold Publishing and Co.

Kyari, M. (2008). Extraction and Characterization of Seed Oils. International Agrophysics, 139142.

Ogala, H., Elinge, C., Wawata, I., Adegoke, A., Muhammad, A., \& Ige, A. (April, 2018). Extraction and Physiochemical Analysis of Desert Date (Balanite Aegyptiaca) Seed Oil. International Journal of Advanced Academic Research , 2- 8. 